\title{
Effect of nitrogen and potash on Early shoot borer (Chilo infuscatellus Snellen) incidence in differently maturing varieties of sugarcane
}

\section{Robin Singh*}

Department of Entomology, College of Agriculture, Chaudhary Charan Singh Haryana Agricultural University, Hisar-125 004 (Haryana), India

\section{Dilbagh Ahlawat}

Department of Entomology, Regional Research Station, Chaudhary Charan Singh Haryana Agricultural University, Karnal-132 001 (Haryana), India

\section{S.S. Yadav}

Department of Entomology, College of Agriculture, Chaudhary Charan Singh Haryana Agricultural University, Hisar-125 004 (Haryana), India

Kanika Nagpal

Department of Entomology, College of Agriculture, Chaudhary Charan Singh Haryana Agricultural University, Hisar-125 004 (Haryana), India

\section{Ankur Chaudhary}

Department of Agronomy, Regional Research Station, Chaudhary Charan Singh Haryana Agricultural University, Karnal-132 001 (Haryana), India

*Corresponding author. E-mail: robinarya977@gmail.com

\begin{abstract}
It has been argued that fertilization may influence the susceptibility of insect pests, and thus, can increase the crop production by lowering the incidence of insect-pest. Here, the present investigation was carried out to study the influence of nitrogen and potash levels on the incidence of early shoot borer, Chilo infuscatellus Snellen in sugarcane varieties at Regional Research Station CCSHAU Uchani farm, Karnal. The experiment was laid out in split-split plot design with three differently maturing varieties viz., Co 0238 , $\mathrm{CoH} 119$ and $\mathrm{CoH} 150$ as main plot, three doses of nitrogen viz., 150, 200 and $250 \mathrm{~kg}$ per hectare (kg/ ha) as sub plot and two doses of potash viz., 0 and $50(\mathrm{~kg} / \mathrm{ha})$ as sub-sub plot. The early shoot borer mean per cent incidence recorded in April, May and June, 2015 was highest (7.68, 12.19 and 6.35 , respectively) in Co 0238 while, lowest $(5.16,8.51$ and 5.40, respectively) in $\mathrm{CoH} 119$ followed by $\mathrm{CoH} 150$ (6.29, 8.79 and 5.43, respectively). In relation to nitrogen application, maximum mean per cent incidence $(7.12,11.19$ and 6.48 , respectively) in April, May and June, 2015 of early shoot borer was recorded at $250 \mathrm{~kg} \mathrm{~N} /$ ha and the minimum $(5.68,8.57$ and 5.23 , respectively) at $150 \mathrm{~kg} \mathrm{~N} / \mathrm{ha}$. Application of potassium significantly reduced the shoot borer infestation with mean per cent incidence lower at $50 \mathrm{~kg} \mathrm{~K}_{2} \mathrm{O} / \mathrm{ha}$ (5.90, 9.24 and 5.33, respectively) in April, May and June, 2015 compared to control i.e., no application of potassium $(6.85,10.42$ and 6.12 , respectively). Results revealed that application of potassium with optimum dose of nitrogenous fertilizer along with selection of suitable variety acted as preventive measures to avoid shoot borer infestation.
\end{abstract}

Keywords: Early shoot borer, Incidence, Nitrogen, Potash, Sugarcane

\section{Article Info}

DOI: 10.31018/jans.v11i2.2013

Received: February 7, 2019

Revised: April 18, 2019

Accepted: April 23, 2019

\section{How to Cite}

Singh, R. et al. (2019).

Effect of nitrogen and potash on Early shoot borer (Chilo infuscatellus Snellen) incidence in differently maturing varieties of sugarcane. Journal of Applied and Natural Science, 11(2): 299- 304 https://doi.org/10. 310 18/jans.v11i2.2013

\section{INTRODUCTION}

Sugarcane Saccharum officinarum, family Poace$a e$ is the most important and industrial crop of India. It is the main source of white industry which is considered the second largest industry after textile in India. Sugarcane is mostly grown in provinces of country namely Uttar Pradesh, Punjab, Haryana, Coimbatore and Ooty over an area of 4.5 million hectares with an annual production of 288 million metric tonnes (Anonymous 2017). The introduction of high yielding varieties and the associated technology have caused tremendous change in the insect pest complex of sugarcane. Only insect-pests cause 20 per cent loss in yield to the sugarcane crop (Dhaliwal et al., 2004). The most important species causing damage to the sugarcane crop are the sugarcane borers, particularly the sugarcane shoot borer (Gul et al., 2008). Early shoot borer, Chilo infuscatellus Snellen is a cosmopolitan pest distributed throughout the India, having a wide host range, is also referred to as polyphagous borer species. Shoot borer is a 
serious pest during summer months i.e. premonsoon period. The shoot borer, $C$. infuscatellus is more active during hot periods of the year both in tropical (Murthy, 1953; Sulaiman, 1954; Jaganatha Rao and Jagannath Rao, 1960; Varadharajan et al., 1972) and subtropical India (Khan and Singh, 1942; Agarwala and Huque, 1955; Gupta, 1959a; Bains and Dev Roy, 1981). The pest multiplies rapidly in hot and dry weather (April to June). The larvae after hatching enter the young shoots and as a result of its feeding the central leaf whorl dries up and forms a dead heart. Some studies revealed that losses caused by sugarcane stem borers are up to 36.51 per cent (Ahmad et al., 2011). This borer has been also found to cause mortality of mother shoots to the extent of 50 per cent (Gupta, 1959b) and 6.4, 27.0 and 75.0 per cent of primary, secondary and tertiary tillers, respectively. It causes loss of 0.3-33.0 per cent in yield, 12.0 per cent in sugar recovery, 2.0 per cent in CCS and 27.0 per cent in jaggery. In terms of cane yield it is equivalent to $0.6-38.78$ tonnes/ha and 0.4-4.2 units of sugar recovery (Chaudhary, 2008).

Gul et al. (2002) reported that the variety Mardan93 significantly received more infestation of shoot borer in both plant and ratoon crops as compared to other candidate varieties in early maturing group. Munir et al. $(2008)$ reported that dead heart percentage was $2.97,3.30$ and 18.34 in early, mid and late maturing varieties, respectively. Vemuri et al. (2013) also found variable rate of infestation in differently maturing sugarcane varieties and reported that genotypes Co $0110,98 \mathrm{~A} 165$, Co 6806 and 98A 125 were least susceptible.

Among the major nutrients, nitrogen enhances tillering and growth of canes, however, high levels of $\mathrm{N}$ fertilisation resulted in heavy damage by shoot borer (Mishra et al., 2004) in sugarcane. Kennedy and Nachiappan (1992) have found that greater contents of potassium increased resistance to $C$. infuscatellus in sugarcane. Agarwal (1959) reported that hardy canes showed minimum attack of shoot borer. Sithanantham and Srinivasan (1972) studied the foliar application of potash for protecting sugarcane against shoot borer and reported that high level of potassium confer resistance to shoot borer.

Efforts are being made to minimize the incidence and the losses caused by borers through integrated pest management. However, information on the comparative susceptibility of differently maturing sugarcane varieties to the early shoot borer under varying levels of nitrogen and potash is quite meager. Therefore, the present investigation was undertaken with the objective to estimate the effect of nitrogen and potash on shoot borer, $C$. infuscatellus Snellen, infestation from Haryana.

\section{MATERIALS AND METHODS}

A field investigation was carried out at Research
Area of CCS HAU Regional Research Station, Karnal located at $29^{\circ} 42^{\prime} \mathrm{N}$ latitude and $77^{\circ} 02^{\prime} \mathrm{E}$ longitude during crop season 2015-16 (MarchJuly, 2015). Three genotypes namely Co 0238 , $\mathrm{CoH} 119$ and $\mathrm{CoH} 150$ which are early, mid and late maturing genotypes, respectively were selected as the test genotypes. Genotypes were planted in $3^{\text {rd }}$ week of March, 2015 with a plot size of $9 \mathrm{~m}$ $x 4.5 \mathrm{~m}$ and seed rate was 90 thousand two budded sett/ha with row to row distance of $75 \mathrm{~cm}$. The experiment was replicated thrice in a split-split plot design with a total of 18 treatments and a total number of 54 plots. Three doses of nitrogen at the rate of 150,200 and $250 \mathrm{~kg}$ per hectare were applied. $1 / 3^{\text {rd }}$ dose of nitrogen was applied at the time of planting in all the plots and remaining $2 / 3^{\text {rd }}$ dose was applied at $2^{\text {nd }}$ and $4^{\text {th }}$ irrigation in the month of May and June, respectively. Application of Potash $\left(\mathrm{K}_{2} \mathrm{O}\right) 50 \mathrm{~kg} / \mathrm{ha}$ was done as basal dose in half the number of plots (27) and in other half (27) no potash was applied. Incidence of early shoot borer was recorded in post-germination phase at 30 days interval up to 120 days (at 30 , 60, 90 and 120 DAP). Meteorological data was also recorded during the study period and has been presented in Table 1. The observations on the total number of shoots and number of dead hearts due to the early shoot borer was recorded from two middle rows ( $3^{\text {rd }}$ row and $4^{\text {th }}$ row) in each plot and per cent incidence was calculated as per the following formula :

$\%$ incidence $=$ Total no. of dead heart $/$ Total no. of shoots $\times 100$ ..........Eq. 1 Data obtained was tabulated and subjected to statistical analysis as per requirement. Before the analysis, the data was converted into percentage. Angular transformation was applied for these parameters.

\section{RESULTS AND DISCUSSION}

\section{Incidence of early shoot borer (C. infuscatellus Snellen)}

Effect of varieties on early shoot borer (ESB):

The mean incidence of early shoot borer recorded in April May and June, 2015 are presented in Table 2. The maximum per cent incidence (7.68, 12.19 and 6.35 ) of ESB was recorded in variety Co 0238 , followed by that in variety $\mathrm{CoH} 150$ (6.29, 8.79 and 5.43) while, minimum incidence (5.16, 8.51 and 5.40) of ESB was recorded in variety $\mathrm{CoH} 119$, during April, May and June 2015, respectively for each month. The present findings are in agreement with the observations made by Singh et al. (2002) who reported that among one hundred thirty one genotypes tested against early shoot borer (C. inluscatellus Snellen), 30 genotypes were rated as tolerant, 48 as moderately tolerant, 52 as susceptible and 1 as highly susceptible. Rao (1962) also reported that the varieties resistant to shoot borer were more vigorous in 
Singh, R. et al. / J. Appl. \& Nat. Sci. 11(2): 299- 304 (2019)

Table 1. Meteorological observations during the study period from $1^{\text {st }}$ week of April to $4^{\text {th }}$ week of June, 2015.

\begin{tabular}{|c|c|c|c|c|c|c|}
\hline \multirow{2}{*}{$\begin{array}{l}\text { Months/ } \\
\text { week }\end{array}$} & \multirow{2}{*}{$\begin{array}{c}\text { Standard } \\
\text { weeks }\end{array}$} & \multicolumn{2}{|c|}{ Weekly Mean Temperature } & \multicolumn{2}{|c|}{ Weekly Mean Relative Humidity } & \multirow{2}{*}{$\begin{array}{c}\text { Weekly } \\
\text { Mean Sun- } \\
\text { shine Hours }\end{array}$} \\
\hline & & $\begin{array}{c}\text { Minimum T } \\
\left({ }^{\circ} \mathrm{C}\right)\end{array}$ & $\begin{array}{c}\text { Maximum T } \\
\left({ }^{\circ} \mathrm{C}\right)\end{array}$ & $\begin{array}{c}\text { RH Morning } \\
(\%)\end{array}$ & $\begin{array}{c}\text { RH Evening } \\
(\%)\end{array}$ & \\
\hline April I, 2015 & 15 & 15.1 & 29.1 & 85 & 39 & 10.5 \\
\hline II & 16 & 17.9 & 31.2 & 82 & 40 & 8 \\
\hline III & 17 & 19.3 & 39.6 & 61 & 20 & 9.6 \\
\hline IV & 18 & 20.7 & 34.9 & 65 & 33 & 9.2 \\
\hline May I, 2015 & 19 & 20.9 & 40.1 & 51 & 15 & 8.4 \\
\hline II & 20 & 21.5 & 37.1 & 70 & 38 & 8.4 \\
\hline III & 21 & 22.9 & 39.9 & 62 & 23 & 10.1 \\
\hline IV & 22 & 24 & 42.8 & 48 & 16 & 9.2 \\
\hline June I, 2015 & 23 & 22.8 & 38.1 & 61 & 31 & 7.3 \\
\hline II & 24 & 24.9 & 40.9 & 58 & 24 & 8.4 \\
\hline III & 25 & 24.8 & 37.3 & 70 & 39 & 8.3 \\
\hline IV & 26 & 25 & 34.5 & 77 & 57 & 8.5 \\
\hline
\end{tabular}

Table 2. Mean per cent incidence of early shoot borer in sugarcane varieties as influenced by nitrogen and potash levels.

\begin{tabular}{|c|c|c|c|}
\hline \multirow{2}{*}{$\begin{array}{l}\text { Treatment } \\
\text { Varieties }\end{array}$} & \multicolumn{3}{|c|}{ Mean per cent incidence of Early Shoot Borer } \\
\hline & April & May & June \\
\hline Co 0238 & $16.03(7.68)$ & $20.36(12.19)$ & $14.56(6.35)$ \\
\hline CoH 119 & 13.09 (5.16) & $16.93(8.51)$ & $13.41(5.40)$ \\
\hline CoH 150 & $14.48(6.29)$ & $17.20(8.79)$ & $13.43(5.43)$ \\
\hline S.E.(m) \pm & 0.18 & 0.22 & 0.06 \\
\hline C.D. @5 \% & 0.70 & 0.85 & 0.23 \\
\hline \multicolumn{4}{|c|}{ Nitrogen levels } \\
\hline 150 & $13.73(5.68)$ & $16.97(8.57)$ & $13.19(5.23)$ \\
\hline 200 & $14.50(6.33)$ & 18.09 (9.72) & $13.51(5.47)$ \\
\hline 250 & $15.37(7.12)$ & 19.43 (11.19) & $14.70(6.48)$ \\
\hline S.E.(m) \pm & 0.28 & 0.18 & 0.11 \\
\hline C.D. @5 \% & 0.87 & 0.56 & 0.33 \\
\hline \multicolumn{4}{|c|}{ Potash levels } \\
\hline $\mathbf{0}$ & $15.08(6.85)$ & $18.72(10.42)$ & $14.29(6.12)$ \\
\hline 50 & $13.99(5.90)$ & $17.60(9.24)$ & $13.31(5.33)$ \\
\hline S.E.(m) \pm & 0.12 & 0.15 & 0.12 \\
\hline C.D. @5 \% & 0.36 & 0.46 & 0.36 \\
\hline
\end{tabular}

Figures in parentheses represent original values and those outside are angular transformed values

Table 3. Mean per cent incidence of early shoot borer in sugarcane varieties as influenced by nitrogen and potash levels in the month of April during 2015-2016.

\begin{tabular}{|c|c|c|c|c|c|c|c|c|c|c|}
\hline \multicolumn{4}{|c|}{ Variety $\times$ Nitrogen } & \multicolumn{4}{|c|}{ Nitrogen $\times$ Potash } & \multicolumn{3}{|c|}{ Variety $\times$ Potash } \\
\hline \multirow{2}{*}{$\begin{array}{l}\text { Nitrogen } \\
\text { (kg/ha) }\end{array}$} & \multicolumn{3}{|c|}{ Variety } & \multirow{2}{*}{$\begin{array}{l}\text { Potash } \\
\text { (kg/ha) }\end{array}$} & \multicolumn{3}{|c|}{ Nitrogen (kg/ha) } & \multirow[t]{2}{*}{ Variety } & \multicolumn{2}{|c|}{ Potash(kg/ha) } \\
\hline & Co 0238 & $\mathrm{CoH} 119$ & $\mathrm{CoH} 150$ & & 150 & 200 & 250 & & 0 & 50 \\
\hline 150 & $\begin{array}{l}14.88 \\
(6.62)\end{array}$ & $\begin{array}{l}12.69 \\
(4.84)\end{array}$ & $\begin{array}{l}13.63 \\
(5.58)\end{array}$ & 0 & $\begin{array}{l}14.32 \\
(6.15)\end{array}$ & $\begin{array}{l}14.92 \\
(6.70)\end{array}$ & $\begin{array}{l}16.00 \\
(7.70)\end{array}$ & $\begin{array}{l}\text { Co } \\
0238\end{array}$ & $\begin{array}{l}16.90 \\
(8.50)\end{array}$ & $\begin{array}{l}15.16 \\
(6.86)\end{array}$ \\
\hline 200 & $\begin{array}{l}16.10 \\
(7.73)\end{array}$ & $\begin{array}{l}12.95 \\
(5.04)\end{array}$ & $\begin{array}{l}14.44 \\
(6.23)\end{array}$ & 50 & $\begin{array}{l}13.15 \\
(5.21)\end{array}$ & $\begin{array}{l}14.07 \\
(5.97)\end{array}$ & $\begin{array}{l}14.75 \\
(6.54)\end{array}$ & $\begin{array}{l}\mathrm{CoH} \\
119\end{array}$ & $\begin{array}{l}13.61 \\
(5.55)\end{array}$ & $\begin{array}{l}12.58 \\
(4.77)\end{array}$ \\
\hline 250 & $\begin{array}{l}17.09 \\
(8.69)\end{array}$ & $\begin{array}{l}13.65 \\
(5.60)\end{array}$ & $\begin{array}{l}15.38 \\
(7.07)\end{array}$ & & & & & $\begin{array}{l}\text { CoH } \\
150\end{array}$ & $\begin{array}{l}14.74 \\
(6.50)\end{array}$ & $\begin{array}{l}14.23 \\
(6.08)\end{array}$ \\
\hline Mean & $\begin{array}{l}16.03 \\
(7.68)\end{array}$ & $\begin{array}{l}13.09 \\
(5.16)\end{array}$ & $\begin{array}{l}14.48 \\
(6.29)\end{array}$ & Mean & $\begin{array}{l}13.73 \\
(5.68)\end{array}$ & $\begin{array}{l}14.50 \\
(6.33)\end{array}$ & $\begin{array}{l}15.37 \\
(7.12)\end{array}$ & Mean & $\begin{array}{l}15.08 \\
(6.85)\end{array}$ & $\begin{array}{l}13.99 \\
(5.90)\end{array}$ \\
\hline
\end{tabular}

S-Significant, N.S.-Non significant, C.D. at $5 \%$, Variety $=0.70(\mathrm{~S})$, Nitrogen $=0.87(\mathrm{~S})$, Potash $=0.36(\mathrm{~S})$, Variety $\times$ Nitrogen $=$ N.S., Nitrogen $\times$ Potash $=$ N.S., Variety $\times$ Potash $=0.63(S)$, Variety $\times$ Nitrogen $\times$ Potash $=$ N.S.

growth and had greater green leaf area than the susceptible varieties.

Effect of Nitrogen and Potash fertilizer levels on early shoot borer (ESB): Data on mean per cent incidence of early shoot borer are presented in Table-2 and data revealed that the mean per cent incidence of early shoot borer was influenced due to different levels of $\mathrm{N}$ and potassium fertilizer application. The highest early shoot borer incidence $(7.12 \%)$ was recorded in $250 \mathrm{~kg} \mathrm{~N} / \mathrm{ha}$ while, the lowest incidence $(5.68 \%)$ of ESB was recorded in $150 \mathrm{~kg} \mathrm{~N} / \mathrm{ha}$ and it was statistically at par with $200 \mathrm{~kg} \mathrm{~N} / \mathrm{ha}(6.33 \%)$. The incidence of shoot borer in potash treated plots $(5.90 \%)$ was 
Singh, R. et al. / J. Appl. \& Nat. Sci. 11(2): 299- 304 (2019)

Table 4. Mean per cent incidence of early shoot borer in sugarcane varieties as influenced by nitrogen and potash levels in the month of May during 2015-2016.

\begin{tabular}{|c|c|c|c|c|c|c|c|c|c|c|}
\hline \multicolumn{4}{|c|}{ Variety $\times$ Nitrogen } & \multicolumn{4}{|c|}{ Nitrogen $\times$ Potash } & \multicolumn{3}{|c|}{ Variety $\times$ Potash } \\
\hline \multirow{2}{*}{$\begin{array}{l}\text { Nitrogen } \\
\text { (kg/ha) }\end{array}$} & \multicolumn{3}{|c|}{ Variety } & \multirow{2}{*}{$\begin{array}{l}\text { Potash } \\
\text { (kg/ha) }\end{array}$} & \multicolumn{3}{|c|}{ Nitrogen (kg/ha) } & \multirow[t]{2}{*}{ Variety } & \multicolumn{2}{|c|}{ Potash (kg/ha) } \\
\hline & Co 0238 & CoH 119 & CoH 150 & & 150 & 200 & 250 & & 0 & 50 \\
\hline 150 & $\begin{array}{l}18.50 \\
(10.10)\end{array}$ & $\begin{array}{l}16.27 \\
(7.88)\end{array}$ & $\begin{array}{l}16.14 \\
(7.75)\end{array}$ & 0 & $\begin{array}{l}17.27 \\
(8.87)\end{array}$ & $\begin{array}{l}18.77 \\
(10.44)\end{array}$ & $\begin{array}{l}20.13 \\
(11.96)\end{array}$ & $\begin{array}{l}\text { Co } \\
0238\end{array}$ & $\begin{array}{l}21.03 \\
(12.95)\end{array}$ & $\begin{array}{l}19.68 \\
(11.42)\end{array}$ \\
\hline 200 & $\begin{array}{l}20.19 \\
(11.95)\end{array}$ & $\begin{array}{l}16.86 \\
(8.43)\end{array}$ & $\begin{array}{l}17.22 \\
(8.79)\end{array}$ & 50 & $\begin{array}{l}16.68 \\
(8.28)\end{array}$ & $\begin{array}{l}17.41 \\
(9.01)\end{array}$ & $\begin{array}{l}18.72 \\
(10.43)\end{array}$ & $\begin{array}{l}\text { CoH } \\
119\end{array}$ & $\begin{array}{l}17.37 \\
(8.94)\end{array}$ & $\begin{array}{l}16.49 \\
(8.08)\end{array}$ \\
\hline 250 & $\begin{array}{l}22.37 \\
(14.51)\end{array}$ & $\begin{array}{l}17.66 \\
(9.23)\end{array}$ & $\begin{array}{l}18.25 \\
(9.84)\end{array}$ & & & & & $\begin{array}{l}\text { CoH } \\
150\end{array}$ & $\begin{array}{l}17.77 \\
(9.36)\end{array}$ & $\begin{array}{l}16.64 \\
(8.22)\end{array}$ \\
\hline Mean & $\begin{array}{l}20.36 \\
(12.19)\end{array}$ & $\begin{array}{l}16.93 \\
(8.51)\end{array}$ & $\begin{array}{l}17.20 \\
(8.79)\end{array}$ & Mean & $\begin{array}{l}16.97 \\
(8.57)\end{array}$ & $\begin{array}{l}18.09 \\
(9.72)\end{array}$ & $\begin{array}{l}19.43 \\
(11.19)\end{array}$ & Mean & $\begin{array}{l}18.72 \\
(10.42)\end{array}$ & $\begin{array}{l}17.60 \\
(9.24)\end{array}$ \\
\hline
\end{tabular}

Figures in parentheses represent original values and those outside are angular transformed values; SSignificant, N.S.-Non significant, C.D. at $5 \%$, Variety $=0.85(\mathrm{~S})$, Nitrogen $=0.56(\mathrm{~S})$, Potash $=0.46(\mathrm{~S})$, Variety $\times$ Nitrogen $=0.97(\mathrm{~S})$, Nitrogen $\times$ Potash $=$ N.S., Variety $\times$ Potash $=$ N.S., Variety $\times$ Nitrogen $\times$ Potash $=$ N.S.

Table 5. Mean per cent incidence of early shoot borer in sugarcane varieties as influenced by nitrogen and potash levels in the month of June during 2015-2016.

\begin{tabular}{|c|c|c|c|c|c|c|c|c|c|c|}
\hline \multicolumn{4}{|c|}{ Variety $\times$ Nitrogen } & \multicolumn{4}{|c|}{ Nitrogen $\times$ Potash } & \multicolumn{3}{|c|}{ Variety $\times$ Potash } \\
\hline \multirow{2}{*}{$\begin{array}{l}\text { Nitrogen } \\
\text { (kg/ha) }\end{array}$} & \multicolumn{3}{|c|}{ Variety } & \multirow{2}{*}{$\begin{array}{l}\text { Potash } \\
\text { (kg/ha) }\end{array}$} & \multicolumn{3}{|c|}{ Nitrogen (kg/ha) } & \multirow[t]{2}{*}{ Variety } & \multicolumn{2}{|c|}{ Potash (kg/ha) } \\
\hline & Co 0238 & CoH 119 & CoH 150 & & 150 & 200 & 250 & & 0 & 50 \\
\hline 150 & $\begin{array}{l}13.92 \\
(5.80)\end{array}$ & $\begin{array}{l}13.15 \\
(5.19)\end{array}$ & $\begin{array}{l}12.50 \\
(4.70)\end{array}$ & 0 & $\begin{array}{l}13.63 \\
(5.67)\end{array}$ & $\begin{array}{l}13.81 \\
(5.71)\end{array}$ & $\begin{array}{l}15.41 \\
(7.09)\end{array}$ & Co 0238 & $\begin{array}{l}14.95 \\
(6.69)\end{array}$ & $\begin{array}{l}14.17 \\
(6.01)\end{array}$ \\
\hline 200 & $\begin{array}{l}14.17 \\
(6.00)\end{array}$ & $\begin{array}{l}13.22 \\
(5.24)\end{array}$ & $\begin{array}{l}13.15 \\
(5.18)\end{array}$ & 50 & $\begin{array}{l}12.75 \\
(4.89)\end{array}$ & $\begin{array}{l}13.21 \\
(5.24)\end{array}$ & $\begin{array}{l}13.99 \\
(5.87)\end{array}$ & CoH 119 & $\begin{array}{l}13.99 \\
(5.86)\end{array}$ & $\begin{array}{l}12.83 \\
(4.94)\end{array}$ \\
\hline 250 & $\begin{array}{l}15.59 \\
(7.24)\end{array}$ & $\begin{array}{l}13.86 \\
(5.77)\end{array}$ & $\begin{array}{l}14.66 \\
(6.42)\end{array}$ & & & & & CoH 150 & $\begin{array}{l}13.92 \\
(5.82)\end{array}$ & $\begin{array}{l}12.95 \\
(5.05)\end{array}$ \\
\hline Mean & $\begin{array}{l}14.56 \\
(6.35)\end{array}$ & $\begin{array}{l}13.41 \\
(5.40)\end{array}$ & $\begin{array}{l}13.43 \\
(5.43)\end{array}$ & Mean & $\begin{array}{l}13.19 \\
(5.23)\end{array}$ & $\begin{array}{l}13.51 \\
(5.47)\end{array}$ & $\begin{array}{l}14.70 \\
(6.48)\end{array}$ & Mean & $\begin{array}{l}14.29 \\
(6.12)\end{array}$ & $\begin{array}{l}13.31 \\
(5.33)\end{array}$ \\
\hline
\end{tabular}

Figures in parentheses represent original values and those outside are angular transformed values; SSignificant, N.S.-Non significant, C.D. at $5 \%$, Variety $=0.23(\mathrm{~S})$, Nitrogen $=0.33(\mathrm{~S}) \quad$ Potash $=0.36(\mathrm{~S})$, Variety $\times$ Nitrogen $=0.58(S)$, Nitrogen $\times$ Potash $=$ N.S., Variety $\times$ Potash $=$ N.S., Variety $\times$ Nitrogen $\times$ Potash $=$ N.S.

significantly less as compared to control plots $(6.85 \%)$ during April. The interaction effects of early shoot borer with variety and nitrogen levels $(\mathrm{V} \times \mathrm{N})$, nitrogen levels and potash levels $(\mathrm{N} \times \mathrm{K})$ and variety, $\mathrm{N}$ levels of fertilizer and $\mathrm{K}$ levels of fertilizer $(\mathrm{V} \times \mathrm{N} \times \mathrm{K})$ were found to be nonsignificant, while, the interaction effects of early shoot borer with varieties and $\mathrm{K}$ levels of fertilizer $(\mathrm{V} \times \mathrm{K})$ was found to be significant and has been shown in Table 3. The lowest per cent incidence of ESB was recorded in variety $\mathrm{CoH} 119$ (4.77\%) at $50 \mathrm{~kg} \mathrm{~K} / \mathrm{ha}$ while, it was highest in variety Co $0238(8.50 \%)$ with $\mathrm{K}$ levels of $0 \mathrm{~kg} / \mathrm{ha}$.

In May, 2015 early shoot borer incidence was significantly the highest $(11.19 \%)$ in $250 \mathrm{~kg} \mathrm{~N} / \mathrm{ha}$ followed by $(9.72 \%)$ in $200 \mathrm{~kg} \mathrm{~N} / \mathrm{ha}$, while, the lowest incidence $(8.57 \%)$ of ESB was recorded in 150 $\mathrm{kg} \mathrm{N} / \mathrm{ha}$. The incidence of shoot borer in potash treated plots $(9.24 \%)$ was significantly less as compared to control plots $(10.42 \%)$. The interaction effects of early shoot borer with variety and nitrogen levels $(\mathrm{V} \times \mathrm{N})$ was found to be significant and are represented in Table 4. Among the three nitrogen levels significantly lowest $(7.75 \%)$ incidence of ESB was recorded in variety $\mathrm{CoH} 150$. While, it was highest in Co $0238(14.51 \%)$ at 250 $\mathrm{kg} \mathrm{N} / \mathrm{ha}$, while, the interaction effects of early shoot borer with nitrogen levels and potash levels $(\mathrm{N} \times \mathrm{K})$, varieties and $\mathrm{K}$ levels of fertilizer $(\mathrm{V} \times \mathrm{K})$ and variety, $\mathrm{N}$ levels of fertilizer and $\mathrm{K}$ levels of fertilizer $(\mathrm{V} \times \mathrm{N} \times \mathrm{K})$ was found non-significant.

During June, 2015 similar observations were recorded as incidence was highest $(6.48 \%)$ in $250 \mathrm{~kg}$ $\mathrm{N} /$ ha, while, the minimum incidence $(5.23 \%)$ of ESB was recorded in $150 \mathrm{~kg} \mathrm{~N} / \mathrm{ha}$ and it was statistically at par with that in $200 \mathrm{~kg} \mathrm{~N} / \mathrm{ha}(5.47 \%)$. The incidence of shoot borer in potash treated plots $(5.33 \%)$ was significantly less as compared to control plots $(6.12 \%)$. The interaction effects of early shoot borer with variety and nitrogen levels $(\mathrm{V} \times \mathrm{N})$ was found to be significant and are presented in Table 5. Among the three nitrogen levels significantly lowest $(4.70 \%)$ incidence of ESB was recorded in variety $\mathrm{CoH} 150$ at $150 \mathrm{~kg} \mathrm{~N} / \mathrm{ha}$. While, it was highest in Co $0238(7.24 \%)$ at 250 $\mathrm{kg} \mathrm{N} / \mathrm{ha}$, while, the interaction effects of early shoot borer with nitrogen levels and potash levels $(\mathrm{N} \times \mathrm{K})$, varieties and $\mathrm{K}$ levels of fertilizer $(\mathrm{V} \times \mathrm{K})$ and variety, $\mathrm{N}$ levels of fertilizer and $\mathrm{K}$ levels of fertilizer $(\mathrm{V} \times \mathrm{N} \times \mathrm{K})$ with early shoot borer was found nonsignificant. The present study is strongly supported by the findings of Pandey and Kumar (2014) who reported that the highest incidence of $C$. infuscatellus was recorded during May, 2009 at 
Hisar, Haryana. Kumar et al. (2004) also observed that the peak active period of the $C$. infuscatellus was in the month of May, 2003 in Andhra Pradesh. The present findings are also in agreement with the observations of Pandya et al. (1996) who reported that no incidence of early shoot borer was recorded during July, August, September and October, 1994. The present study is strongly supported by the findings of Mishra et al. (2004) who reported that lesser number of irrigation with higher $\mathrm{N}$ levels cause favourable effect on multiplication of shoot borer in sugarcane ratoon. Similar observations were recorded by Sithanantham and Srinivasan (1972) that the high level of potassium confer resistance to shoot borer in sugarcane at coimbatore.

\section{Conclusion}

Field experiment based on the effect of nitrogen and potash on the incidence of shoot borer, $C$. infuscatellus Snellen in different maturity groups of sugarcane genotypes revealed that early shoot borer incidence was highest $(7.68,12.19$ and $6.35)$ in Co 0238 whereas lowest $(5.16,8.51$ and 5.40) in CoH 119 in April, May and June, 2015, respectively. Regarding fertilizer application, shoot borer incidence was more $(7.12,11.19$ and 6.48) under higher level of nitrogen i.e. $250 \mathrm{~kg} \mathrm{~N} / \mathrm{ha}$ while reverse case in potassium fertilization i.e lower $(5.90,9.24$ and 5.33) incidence at higher level of potassium in April, May and June, 2015, respectively. Hence, balanced fertilizer is not only important for soil health perspectives but also helps in management of insect-pest in sugarcane crop.

\section{REFERENCES}

1. Agarwal, R.A. (1959). Insect resistance in Coimbatore canes - A review. Indian Sugar, 8(12): 785-796.

2. Agarwala, S.B.D. and Huque, M.W. (1955). Studies on Argyria sticticraspis Hmpsn., the early shoot borer of sugarcane in Bihar. Indian Journal of Entomology, 17: 307-314.

3. Ahmad, S., Ashfaq, M., Afzal, M., and Aqeel, A. (2011). IPM module for the sustainable management of sugarcane stem borer in Pakistan. International Journal of Agriculture and Applied Sciences, 3:76-79.

4. Anonymous (2017). Sugar Annual. https:// gain.fas.usda.gov/Recent\%20GAIN

5. Bains, S.S. and Dev Roy, J.C. (1981). Integrated management of sugarcane pests in the Punjab. "Proceedings of the National Symposium on Stalk borer, Chilo auricilius Dudgeon" 20-22 April, 1981, H.A.U. Regional Research Station, Karnal, pp 147155

6. Chaudhary, O.P. (2008). Control of different Borers in sugarcane crop. Co-operative Sugar, 40(3): 29-38.

7. Dhaliwal, G.S., Arora, R. and Dhawan, A.K. (2004). Crop losses due to insect-pests in Indian Agriculture: An update. Indian Journal of Ecology, 31(1): 1-7.

8. Gul, F., Ahmad, G., Khan, M. and Ikramulla. (2002). Studies on preference/non-preference of sugarcane varieties to the attack of different borers in Peshawar
Valley conditions of NWFP. Pakistan Sugar Journal, 22(4): 18-21.

9. Gul, F., Nadeem, M. and Inayatullah. (2008). Effect of different control methods on the infestation of borer in sugarcane plant and ratoon crop. Sarhad Journal of Agriculture, 24: 34-39.

10.Gupta, B.D. (1959a). The Insect pests of sugarcane in India. V. The shoot borer, Chilotraea infuscatellus Snell. Indian Sugar, 9:445-465.

11.Gupta, B.D. (1959b). Insect pest of sugarcane in India-V. The shoot borer, Chilotraea infuscatellus Snell. Indian Sugar, 10(1): 67-68.

12.Jaganatha Rao, E. and Jagannath Rao, R. (1960). Some studies on the control of shoot borer (Chilotraea infuscatellus Snell.) in Bobbili tract (Andhra Pradesh). Indian Journal of Sugarcane Research and Development, 5:149-154.

13.Kennedy, F.J.S. and Nachiappan, R. (1992). Certain anatomical, physical and chemical basis for different preference of early shoot borer (Chilo infuscatellus) in sugarcane. International Symposium on Crop Protection, 57: 637-644.

14.Khan, Rahman, A. and Singh, D. (1942). Bionomics and control of sugarcane stem borer, Argyria sticticraspis. Proceedings of the Indian Science Congress, 29: 177

15.Kumar, S., Maheshwari, T.U. and Rao, N.V. (2004). Biology and seasonal incidence of sugarcane early shoot borer Chilo infuscatellus Snellen in Southern zone of Andhra Pradesh. Indian Journal of Entomology, 66(3): 246-250.

16.Mishra, D.N., Kumar, K. and Singh, L.R. (2004). Effect of irrigation and nitrogen levels on the incidence of shoot borer and their impact on yield of sugarcane ratoon. Environment and Ecology, 22(1): 95-97.

17.Munir, M., Afzal, M., Chatta, A.A. and Khan, H.W.A. (2008). Screening of early and medium/Late maturing sugarcane varieties/lines against borer complex infestation in central Punjab. Pakistan Journal of Agricultural Research, 46(4): 373-378.

18.Murthy, D.V. (1953). Cultural and mechanical methods of control of early shoot borer in sugarcane. Proceedings of Annual Convention the Sugar Technologists' Association of India, 22: 119-124.

19.Pandey, S.K. and Kumar, R. (2014). Impact analysis of weather factors in relation to early shoot borer (Chilo infuscatellus Snellen) incidence in summer planted sugarcane after wheat harvest in sub tropics. Indian Journal of Agricultural Research, 48(3): 227 231.

20.Pandya, H.V., Patel, C.B., Patel, J.R., Patel, M.B., Patel, K.K., Patel, J.M. and Mehta, V.R. (1996). Assessment of losses due to root borer in sugarcane. Bhartiya Sugar, 21(3): 19-20.

21.Rao, D.V.S. (1962). Studies on the resistance of sugarcane to the early shoot borer, Chilotraea infuscatellus Snell. M. Sc. Thesis, Andhra University, Waltairs.

22.Singh, M., Madan, Y.P., Singh, D., and Mahla, J.C. (2002). Incidence of early shoot borer, Chilo infuscatellus in different sugarcane genotypes under field conditions. Agricultural Science Digest, 22(4).

23. Sithanantham, S. and Srinivasan, T.R. (1972). Influence of foliar application of potash with endrin protecting sugarcane from shoot borer, Chilo infuscatellus. Indian Journal of Agricultural Chemistry, 5:2531 
Singh, R. et al. / J. Appl. \& Nat. Sci. 11(2): 299- 304 (2019)

24.Sulaiman, M. (1954). The influence of climate on the population of sugarcane borer in Hyderabad State. Proceedings of the Biennial Conference of Sugarcane Research and Development Workers, India, 2: 155-16.

25.Varadharajan, G.K., Saivaraj, K., Sathiamoorthy, A.S., Subramaniam, A. and Kuppuswami, N.T.
(1972). Sugarcane borers at Cuddalore (Tamil Nadu). Indian Sugar, 21: 817-820.

26.Vemuri, S., Suresh, K. and Kumar, M.V. (2013).

Evaluation of sugarcane germplasm against early shoot borer (ESB), Chilo infuscatellus Snellen. ZENITH International Journal of Business Economics \& Management Research, 3(9): ISSN 2249- 8826 